\title{
Culture Teaching in Historical Review: On the Occasion of ASOCOPI's Fiftieth Anniversary
}

\author{
Una revisión teórica de la enseñanza de la cultura: \\ en honor al quincuagésimo aniversario de ASOCOPI*
}

\author{
Bryan Meadows \\ meadowsb@fdu.edu \\ Fairleigh Dickinson University, Teaneck, USA
}

This literature review surveys fifty years of English language teaching scholarship on the topic of culture teaching. The review segments the available literature according to decade and applies two guiding questions to each resource found: How is culture defined and What does culture teaching look like. The report of findings details how authors in each decade literature set define culture and culture teaching. Discussion of the findings offers general observations of developments as well as consistencies over the entire literature set (1965-2015). This literature review will be of interest to current and emerging English language teaching scholars involved in culture teaching scholarship. It is dedicated to ASOCOPI's fifty-year anniversary (1965-2015).

Key words: Culture, culture teaching, history of language teaching, English language teaching.

Esta revisión teórica examina cincuenta años de literatura sobre la enseñanza de la cultura dentro de la enseñanza del inglés. La revisión divide la literatura disponible por décadas y se formulan dos preguntas que guían el análisis: ¿Cómo se define "cultura”? y ¿Cómo se presenta la enseñanza de la cultura? Los resultados muestran, por década, la definición de cultura y su enseñanza según es vista por los autores revisados. En la discusión de los resultados se presenta el panorama general de la literatura revisada

* Received: January 27, 2016. Accepted: March 21, 2016.

How to cite this article (APA 6th ed.):

Meadows, B. (2016). Culture teaching in historical review: On the occasion of ASOCOPI's fiftieth anniversary. HOW, 23(2), 148-169. http://dx.doi.org/10.19183/how.23.2.294.

This article is licensed under a Creative Commons Attribution-NonCommercial-NoDerivatives 4.0 International License. License Deed can be consulted at http://creativecommons.org/licenses/by-nc-nd/4.0/. 
(1965-2015) mostrando la evolución de cultura y su enseñanza, al igual que los patrones comunes en la misma. Este artículo puede ser de interés para los académicos en el campo de la enseñanza del inglés que abordan estudios sobre la enseñanza de cultura. Este artículo está dedicado a ASOCOPI en honor a su quincuagésimo aniversario.

Palabras clave: cultura, enseñanza de cultura, enseñanza del idioma inglés, historia de la enseñanza de idiomas.

\section{Introduction}

In recognition of ASOCOPI's fifty-year anniversary, the current paper surveys five decades (1965-2015) of culture teaching in English language teaching (ELT) scholarship. The review segments the available literature according to decade and applies two guiding questions to each resource found: How is culture defined and What does culture teaching look like. The current paper reports on the findings of that investigation. It notes the general developments in how authors have treated culture teaching in their publications and provides illustrative references to the literature set. From the onset, it is important to clarify that the review is not a meta-analysis of published studies nor is it a case for a set of best methods. This literature review will be of interest to current and emerging ELT scholars involved in culture teaching scholarship.

\section{Method}

The first stage was collecting resources. A variety of resources (e.g., books, book chapters, journal articles, government publications) were located using online research databases, bibliographies, and the online search functions of major ELT journals (e.g., TESOL Quarterly, ELT Journal, RELC Journal, Colombian Applied Linguistics Journal, PROFILE, and HOW Journal). There were two inclusion criteria. First, the resources must have been published between 1965 and 2015. Second, the resources must approach culture-as-content (i.e., culture as a thing to be taught) which led the analyst to resources written from an English as a foreign language (EFL) standpoint (and in later years, English as an international language [EIL], English as a lingua franca [ELF], and World Englishes [WE]). Table 1 summarizes the results of the literature search. In total, 128 resources were located that fit the two selection criteria. There were four types of resources, arranged according to frequency: journal articles, books (monographs and edited volumes), book chapters/proceedings entries, and other (bibliographies, government publications, ERIC entries). The second stage, analysis of resources, was applied to the 128 items found. 
Table 1. Summary of Resources

\begin{tabular}{||l|c|c|c|c|c|c|c||}
\hline \multicolumn{1}{|c|}{ Decade } & 1960 s & 1970 s & 1980 s & 1990 s & 2000s & 2010 s & Totals \\
\hline Journal articles (peer-reviewed) & 9 & 7 & 6 & 16 & 31 & 13 & 82 \\
\hline $\begin{array}{l}\text { Books (monographs, edited } \\
\text { volumes) }\end{array}$ & 2 & 3 & 4 & 6 & 6 & 2 & 23 \\
\hline $\begin{array}{l}\text { Book chapters / Proceedings } \\
\text { entries }\end{array}$ & 1 & 4 & 6 & 1 & 2 & 3 & 17 \\
\hline $\begin{array}{l}\text { Other (bibliographies, } \\
\text { government publications, ERIC } \\
\text { entries) }\end{array}$ & 1 & 1 & 1 & 0 & 2 & 1 & 6 \\
\hline Totals & 13 & 15 & 17 & 23 & 41 & 19 & 128 \\
\hline \hline
\end{tabular}

The second stage was to analyze the content of the readings found. For convenience purposes, the analyst compartmentalized the readings according to decade. Moving chronologically from earliest to most recent, the analyst investigated each decade group as a stand-alone data set. The analyst applied close reading to all resources in each decade. Close reading consisted of the following steps: (a) examine each reading for responses to two guiding questions (see Figure 1); (b) summarize responses for each reading on a grid so that all results for each decade can be viewed at the same time; (c) identify patterns (similarity/distinction) in summary responses across readings within each decade. With each decade synthesis text completed, it was then possible to construct a general outline that organized the findings of each decade into a single document text. This single document allowed the analyst to develop general observational claims regarding developments in the field over the time frame in question (1965-2015).

1. How is culture being defined in this reading?

a. Theoretical orientation?

b. Key debates being addressed?

2. How is culture teaching being defined in this reading?

a. What is the content of culture to be taught? (i.e., culture teaching standards)

b. What is the goal of culture teaching? (i.e., culture teaching learning objectives)

c. What are the classroom methods being promoted? (i.e., specific instructional techniques)

Figure 1. Analysis Guiding Questions 
The findings of the analysis are limited to the resources the analyst was able to locate using his academic training (in the United States) and searching from his residence (in the United States). Looking through the reference list, the reader will notice a bias for English-language and US-centric publications. Therefore, the findings presented below must be interpreted with those important limitations in mind. The current review paper provides one perspective on the ELT field and should sit in complement to other literature reviews in circulation.

\section{Analysis Findings}

\section{$1960 s$}

A number of resources in the 1960s set were written for audiences of foreign language teachers in the United States (i.e., teachers of Spanish, teachers of French, etc.). It is likely that the literature search process led to these authors because the ELT literature on culture teaching at this time was still emerging. The conceptual foundations that these authors established in the 1960s have had a lasting impact on language education scholarship, including that of the ELT field.

What is culture? Scholars of culture teaching in the first literature set (1960s) draw on structural anthropology in conveying interpretations of culture (Lewald, 1963; Trager, 1962). Many writers in this set go to great lengths to draw a distinction between culture-as-aesthetics (i.e., Big-C culture) and culture-as-everyday life (i.e., Little-C culture), and work to align contemporary culture teaching with the latter. This set of authors defines culture as a system of shared and learned behavior (Brooks, 1969; Imhoof, 1968; Seelye, 1968), supporting their claims with empirical description and analogies between linguistic and cultural systems. Nationalized cultures are presupposed in this literature also. A representative definition from the literature set is the following, presented by Trager (1962) writing to an audience of foreign language educators in the United States:

[Culture is] the system of learned and shared behavior [according to] which the members of society behave and interact... And they can only do these things in terms of their own particular culture, because they know no other way. (p. 135)

What does culture teaching look like? The content of culture teaching in this set follows from structural understandings of culture. The argument is for culture teaching that addresses Little-C culture, the everyday life for speakers of the target language. In the 1960s readings, language is such a primary content for language teachers that curriculum design and learning objectives are informed by language learning goals first and culture second (Fischer, 1967), carrying a theoretical stance made earlier in Lado (1957). Trager (1962), however, makes the opposing argument. 
The endpoint for culture teaching is not assimilation but for students to develop insights into a target culture community while maintaining an observer's perspective (Beaujour, 1969; Matthies, 1968; Povey, 1967; Trager, 1962), an obvious appropriation of the emic/etic distinction central to anthropology. The term, intercultural education, appears in this literature but it carries a different denotation from present usage. For authors like Debyser (1968), intercultural competence is about preparing students with cultural knowledge so that they can avoid cultural mishaps in the target culture. In this literature set, there is some acknowledgment of intra-culture variation and its value to culture teaching (Lewald, 1963), but little guidance on how to make that happen in a language classroom setting.

Instructional techniques promoted in this literature include the following: weaving cultural knowledge into audio-lingual drills (Fischer, 1967; Matthies, 1968; Seelye, 1968), role-plays, descriptive study (Brooks, 1969), comparative/contrastive analysis of cultural variables (Debyser, 1968), and authentic materials. Culture capsules and cultural assimilators, well-known culture teaching materials in the present day, are developed during this time too.

The culture capsule (Taylor \& Sorenson, 1961) provides language teachers with a systematic survey of referential knowledge about a target nationalized culture. The capsule details cultural aspects related to multiple domains such as technology, economic organization, social organization, political organization, worldview, esthetics, education, and subcultures. The cultural items that go into the capsule are selected for their anticipated contrast between the home culture of the students and the target culture of the classroom. Whereas the culture capsule is focused on referential knowledge about a particular culture, the cultural assimilator exercise is intended to draw student sensitivity to cultural perceptions which may differ from their home culture (Lafayette, 1978). The assimilator exercise takes students through a series of critical incidents which involve a miscommunication or misunderstanding due to contrastive cultural perceptions. With each critical incident scenario, students are to select from several possible responses and then receive feedback on the appropriateness of the response they selected. Since their emergence in the 1960s, both the culture capsule and the cultural assimilator technique are widely available online at present.

\section{$1970 s$}

What is culture? Resources in the 1970s set continue the advocacy for Little-C culture teaching noted in the 1960s literature (Lafayette, 1978; Weiss, 1971). As was clear in the 1960s set, authors in the 1970s group primarily reference anthropologists in the definitions of culture they present to language educator audiences (E. Hall, 1976; Nababan, 1974; Trivedi, 1978). Reflecting this deference to structural anthropology, authors define culture as a system of practices, beliefs, and shared values of a group (Blatchford, 1973; Saville-Troike, 1978). 
Descriptions are supported by itemized lists constructed from the ethnographic method (e.g., greeting patterns, patterns of politeness, verbal taboos, family structure, school practices, career paths, kinesics, etc.). Additionally, the link between nation and culture is presupposed as authors detail comparisons of nationalized cultures (Jacobson, 1976). A representative example of culture definition from this set is provided below, presented by Saville-Troike (1978) who was writing for an audience of bilingual educators in the United States. In referencing underlying values and beliefs, Saville-Troike's (1978) definition effectively bridges the 1980s decade set where an interest in the non-observable cultural elements becomes more pronounced.

[Culture] includes all of the rules for appropriate behavior which are learned by people as a result of being members of the same group, and also the values and beliefs which underlie [those] overt behaviors. (Saville-Troike, 1978, p. 5)

What does culture teaching look like? For authors in the 1970s set, the content of culture teaching is found in the everyday experiences of native speakers of the target language (Blatchford, 1973; Scanlan, 1979; Weiss, 1971). Holmes and Brown (1976) recognize that there is inherent variation within any single culture, but argue that the focus of culture teaching is on native expectations and norms in the most general contexts. The debate between language-first or culture-first teaching continues in the 1970s set (Lafayette, 1978; Nababan, 1974). An important development in the 1970s literature was an explicit caution against aiming for objective analysis of cultures (Saville-Troike, 1978). This is a precursor of later poststructuralist challenges to positivism. In the 1970s resources, the endpoint for culture learning is communicative competence. The authors develop the concept along two lines. One, communicative competence is about helping students to avoid cultural pitfalls during participation in target culture daily life (Seelye, 1977). Two, the concept is related to the interpreter role (Nababan, 1974), one's ability to mediate two cultural groups. This focus on developing students who can interpret cultures is a precursor of subsequent evolutions of the term, intercultural competence.

The 1970s authors report the development of instructional materials and activities that are consistent with anthropological perspectives (Jacobson, 1976; Lafayette, 1978; Scanlan, 1979; Taylor, 1970). These include contrastive analyses of nationalized cultures, culture capsules, cultural assimilators, role-plays, discussions, fill-in-the-blunder exercises, authentic materials of various text types, and interpretation of authentic materials. Prominent authors of this time period (Lafayette, 1978; Lafayette \& Schulz, 1975; Nostrand \& Nostrand, 1970; Seelye, 1977) also developed assessment techniques for culture teaching. Lafayette (1978), in particular, develops a lengthy critique of the current condition of culture teaching, noting the outdated reliance on Big-C culture and the audio-lingual method in contemporary foreign language classrooms in the United States. 


\section{$1980 s$}

What is culture? The 1980s resources continue with the basic components of culture developed in the 1960s and 1970s literature including the distinction between observable (e.g., practices/products) and non-observable (e.g., beliefs/values) cultural characteristics. ${ }^{1}$ Scholars also elaborated the subjective dimension of culture, viewing culture as a system of meaning-making and of experiencing the world (Krasnick, 1982; Murphy, 1988). Therefore, authors in the 1980s set stress cultural relativity, the willingness to accept that cultural frames help define one's perception and that the line between polite and impolite, for example, depends on the cultural context (Alptekin \& Alptekin, 1984; Crawford-Lange \& Lange, 1984). Another development in the 1980s set is increased sensitivity to the diverse and dynamic nature of otherwise coherent cultures (Nostrand, 1989). These two together lead authors in the 1980s set to complicate attempts at objective descriptions of cultures, something which had been suggested in earlier years. One sample definition excerpted from Murphy (1988) illustrates the dualistic interpretation of culture, as something both objective and subjective simultaneously. Murphy writes that on top of both traditional aesthetic understandings of culture and more recent understandings of culture as human everyday action on nature, one must further acknowledge that

[c]ulture is a process through which experience is categorized and interpreted. In other words, it is a way of perceiving, interpreting and creating meaning. It is a symbolic activity, and might be defined as shared meanings. (Murphy, 1988, p. 156)

What does culture teaching look like? Discussions of culture teaching in the 1980s set continue, in part, previous debates while also introducing new ones. The question of whether or not culture objectives should guide language teaching is a debate carried over from previous decades (Allen, 1985; Higgs, 1988; Krasnick, 1982; Murphy, 1988; Strasheim, 1981). Additionally, attempts to formalize culture teaching objectives for the purpose of assessment appear in the 1980s set, a carry-over from the 1970s literature (Damen, 1987).

Two new lines of discussion emerge in the 1980s set. The first is a shift in how authors interpret the endpoint of student culture learning. This shift can be characterized as a transition from culture-specific to culture-general. Basically, authors such as Strasheim (1981) look to culture teaching as primarily about preparing students for participation in unfamiliar cultural settings, the details of which cannot always be pre-determined or fully anticipated (i.e., culture-general). This contrasts with previous visions in which the goal of culture teaching is to prepare students for particular culture settings, the details of which are

1 The duality of observable and non-observable cultural traits is formalized in the 1990s ELT literature as the familiar cultural iceberg metaphor. Both Oxford (1995) and Young, Sachdev, and Seedhouse (2009) attribute the analogy to the anthropological work of Edward T. Hall. 
pre-determined (i.e., culture-specific). A culture-general orientation recasts what it means to develop student intercultural competence. Whereas previous interpretations referred to student competence to avoid cultural pitfalls in a specific target culture, under the culture-general orientation, intercultural competence becomes a set of general skills, attitudes, and knowledge that allows students to quickly recognize cultural patterns in unfamiliar settings and to effectively navigate them. Extending from the culture-general take on intercultural competence, authors in the 1980s set identify student intercultural identity as a primary goal for culture teaching. Intercultural identity requires students to adopt self-reflexive cultural stances that will allow them to mediate cultural groups and to interpret one culture in terms of the other (Allen, 1985; Alptekin \& Alptekin, 1984; Crawford-Lange \& Lange, 1984; Ramsey, 1981). A second emerging discussion in the 1980s set is the question of whose cultural experiences should serve as the model for ELT culture teaching (Alptekin \& Alptekin, 1984; Kachru, 1982). This debate continues into the present day. In these early treatments of the topic, one can see the beginnings of a critical turn to ELT that emerges in the subsequent decade.

Authors in the 1980s resources promote specific materials and techniques for culture teaching. They demonstrate the collective effort to develop culture teaching materials that are consistent with contemporary understandings of culture (i.e., skills, behaviors, and attitudes). Specific techniques are familiar such as the culture capsule, culture assimilator, critical incidents, role-plays, and quizzes (Allen, 1985; Damen, 1987; Krasnick, 1982; Morain, 1983). Ethnography is noted as a promising technique for students (Morain, 1983). Other authors argue for the value of student exposure to cultural variation (Crawford-Lange \& Lange, 1984; Nostrand, 1989). Additional culture teaching techniques are specifically branded as outdated during this time: culture facts trap (Crawford-Lange \& Lange, 1984) and activities centered on contrastive cultural analysis. The 1980s literature set also reveals scholar critique of teacher education programs, which are characterized as disjointed from contemporary ELT scholarship (Kramsch, 1987; Morain, 1983).

\section{$1990 s$}

What is culture? The 1990s literature set represents continued development in how ELT scholars define the concept of culture. Most striking about the 1990s set is the influx of poststructuralist thought on culture theory (e.g., Atkinson, 1999; Holliday, 1999; Kramsch, 1998; Kubota, 1999; Pennycook, 1999). Authors articulate active challenges to essentialism, which is pre-determining a person's views, attitudes, beliefs, or practices based on generalized characteristics of a given cultural group. Static and internally coherent categories of culture of earlier decades are replaced in the 1990s set with dynamic, fluid, and emergent ones (Oxford, 1995). Scholars in this set also promote culture as a form of social practice and subjective schema of meaning-making (Atkinson, 1999; Kramsch, 1998). The poststructuralist positions 
adopted by authors in the 1990s elaborate critical arguments introduced in the 1980s literature and continue to push ELT farther away from culture as an objective reality that can be revealed in positivistic social science.

Power also enters into the conversation during this time (Atkinson, 1999) as ELT scholars challenge received sources of authority in culture teaching. One area of challenge concerns the analytical value of the term, culture, due to its vagueness and frequent essentializing to nations (Holliday, 1999). A second challenge is to the received authority of BANA (British/Australian/North American) cultural models in culture teaching (Kubota, 1999; Pennycook, 1999; Widdowson, 1994). Given the global expansion of English and ELT, authors question if BANA models necessarily are always the most prudent models for culture teaching.

A sample definition from the 1990s set is found in Atkinson (1999), who was writing in TESOL Quarterly. This definition captures the increasing complexity of culture brought on by poststructuralist challenges to clear categories and broad generalizing statements about culture.

Cultures can be said to exist... to the extent that schemas or neural networks (arguably, in the head) and social practices, tools, and products (arguably, in the world) are shared across individuals and situations.... But improvisation, indeterminacy, and change are also inevitable ... because no one can be said to share exactly the same set of schemas/neural networks or experiences with the world ... neither can any two people be said to share precisely the same cultures. (Atkinson, 1999, p. 640)

What does culture teaching look like? Reading through the 1990s resources, one identifies a gradual abstraction away from clearly-defined content for culture teaching. As developed in the 1980 s set, authors promote a culture-general orientation such that effective culture teaching prepares students for as-yet-unpredictable intercultural settings (Byram, 1997). An analogy for the turn away from substance (i.e., culture-specific to culture-general) would be the following. One might imagine a painting hanging on a museum wall. The oil painting inside of the frame can be seen as the teachable content in a culture-specific orientation. Take away the painting and only the frame is left. That frame becomes the content for culture teaching under the culture-general orientation. Under a culture-general orientation, there is less reason to walk students through exhaustive item-by-item comparisons of two nationalized cultures and more reason to engage students in critical self-reflection activities in the classroom (Atkinson, 1999; Byram, 1997; Crozet, Liddicoat, \& Lo Bianco, 1999; Kramsch, 1998; Oxford, 1995). The culture-general orientation, supported by a critical lens, lends itself to culture teaching that is expressly inclusive. Historically marginalized cultural groups now have legitimate entrée into culture teaching curricula (Atkinson, 1999; Kubota, 1999). 
Two influential scholars of this time are Byram $(1992,1997)$ and Kramsch $(1993,1998)$. Byram's model of Intercultural Communicative Competence (1997) comes to dominate European-centered scholarship in the 1990s. Briefly, the model consists of five savoirs. The first four savoir components, (skills of interpreting/relating; skills of discovery/interaction; knowledge of self/other; attitudes of curiosity/openness) feed into a fifth component at the center anchoring the entire model: critical cultural awareness (the ability to adopt multiple vantage points allowing for critical interpretation of self/other). Kramsch's (1998) definition of culture becomes dominant in US-centered scholarship: "membership in a discourse community that shares a common social space and history, and common imaginings" (p. 10). Her treatment in this volume also foreshadows her later contributions to the culture teaching literature: culture as mobile (Kramsch, 2015) and symbolic competence (Kramsch, 2006).

In this set of readings, authors aspire for students to experience an eventual change in self in the direction of recognizing the cultural basis to self/other perceptions. Such a stance of cultural relativity then allows students to effectively mediate across cultures. This endpoint state is understood as various terms in the 1990s set: tertiary socialization (Byram, 1992; Simpson, 1997), intercultural communicative competence (Byram, 1997), intercultural competence (Crozet et al., 1999; Kramsch, 1998), and third places (Kramsch, 1993). As Byram (1997) explains, this endpoint places the focus of culture teaching on the interpersonal relationships shared between individuals in intercultural settings.

Authors describe an array of classroom techniques best suited for poststructuralist conceptualizations of culture: student investigative projects (Simpson, 1997), ethnographies (Byram, 1992; Holliday, 1999), student portfolios, explicit teaching of strategies for cultural awareness using student first language (Byram, 1997; Oxford, 1995), and perspective-taking exercises where students explore cultural boundary lines (Kramsch, 1993). At the same time, other familiar techniques make appearances (e.g., culture capsules and role-plays). Teaching methods associated with the culture-as-knowledge approach (e.g., travel facts and cultural trivia) are regularly critiqued in the 1990s resources as outdated. Authors express dissatisfaction with teacher education programs and with methods of assessment (Byram, 1992, 1997; Moore, 1995; Moore, Morales, \& Carel, 1998). Assessment is critiqued for not representing contemporary understandings of culture as systems of meaning-making and the importance of perspective-taking (Moore, 1995). One corrective response is found in Byram (1997), who offers a detailed treatment of assessment for intercultural communicative competence in the context of foreign language classrooms.

\section{$2000 s$}

What is culture? Authors in the 2000s group continue the poststructuralist turn to culture. In these writings, culture is approached as dynamic, diverse, and emergent-a set of 
symbolic tools for meaning-making that are learned and shared in group settings of inequity (Agudelo, 2007; Baker, 2009; Guest, 2002; Roberts, Byram, Barro, Jordan, \& Street, 2001; Singh \& Dogherty, 2004; Turizo \& Gómez, 2006). A representative definition from this literature can be found in Álvarez and Bonilla (2009) who have written in PROFILE. The example illustrates the layers of complexity that are added on to definitions of previous decades. For example, the 1980s interest in the cognitive dimensions of culture is present in the Álvarez and Bonilla (2009) excerpt, as is the 1990s poststructuralist attention to dynamic groupings. What is new is the central place for culture as dynamic and culture as a framework of interpretation.

[Culture] is not a monolithic or a static phenomenon; on the contrary, dynamism is one of its main features . . . culture is a sphere of knowledge (Ramírez, 2007) ${ }^{2}$ in which the frameworks of assumptions, ideas and beliefs that can be used to interpret people's actions, patterns of thinking and human artifacts (art, literature, etc.) lie at the core. (Álvarez \& Bonilla, 2009, p. 161)

Generally speaking, one witnesses in the 2000s literature set a re-aligning of the culture notion to be in tune with globalized realities. Authors in the 2000s continue to develop poststructuralist thought along three specific strands: (1) culture-as-product to cultureas-process (Atkinson, 2004; Tseng, 2002; Turizo \& Gómez, 2006), (2) interest in power for cultural reproduction as well as transformation (Agudelo, 2007; Álvarez \& Bonilla, 2009; De Mejía, 2006; Kramer, 2000), (3) challenge to traditional bases of cultural authority (e.g., BANA cultural models: white, native speakers, standard varieties) as argued in Baker (2009), Nault (2006), and Pennycook (2000). Also present is a growing body of work that explores cultural global flows (Risager, 2000, 2007; Singh \& Dogherty, 2004) thus challenging the integrity of nationalized cultures. In their review of culture teaching literature, Byram and Feng (2004) note a reliance on the ethnographic method to generate cultural knowledge in the 2000s, thus continuing a connection between ethnography and ELT culture theory that was established earlier in the 1960s scholarship.

What does culture teaching look like? By the 2000s, intercultural communicative competence (Byram, 1997) had become the content for culture teaching (Agudelo, 2007; Álvarez \& Bonilla, 2009; Baker, 2009). In a historical overview, Álvarez (2014) remarks that the shift to intercultural perspectives was rapid in the context of Colombian ELT scholarship. In other reviews of the literature, Young et al. (2009) and Paige, Jorstad, Siaya, Klein, and Colby (2000) note that there are many models of intercultural competence in circulation during this time period, however, Byram and Feng (2004) point out the lack of empirical evidence as to their positive impact on student learning. Also notable in this literature set is Kramsch's (2006) proposal to replace communicative competence with symbolic competence. In

2 Ramírez, L. (2007). Comunicación y discurso [Communication and discourse]. Bogotá, CO: Magisterio. 
conjunction with the challenge to received definitions of culture, authors in this time call for a re-tooling of culture teaching for emerging areas of ELT that are self-consciously global in scope such as EIL, ELF, and World Englishes (Baker, 2008, 2009; Broady, 2004). In these domains, the privileging of traditional BANA cultural models-native speaker and nationalized cultures-is vigorously called into question. Given the heightened attention to global landscapes, ELT scholars in this period who stay within the comfortable confines of nationalized boundaries appear disjointed from global realities.

As the content of culture teaching shifts to intercultural communicative competence, so too does the endpoint of culture teaching (Agudelo, 2007; Álvarez \& Bonilla, 2009; Atay, Kurt, Çamlibel, Ersin, \& Kaslioglu, 2009; Baker, 2008; Barletta, 2009, Broady, 2004; Byram \& Feng, 2004; Cruz, 2007, Guest, 2002; Roberts et al. 2001, Turizo \& Gómez, 2006). The goal in the 2000s is an intercultural speaker (Risager, 2007; Roberts et al., 2001), one who can mediate between two cultures and operate within liminal, third spaces. Adding to this, De Mejía (2006) sees intercultural competence as intertwined with critical transformation and language learner empowerment.

Authors in the 2000s recommend a variety of techniques for culture teaching. Dialogues, critical encounters, role-plays, and mediation tasks are still present (Paige et al., 2000). Other techniques include reading assignments, journals, guest speakers, micro-teaching, and diversity workshops (Agudelo, 2007). One also sees discussion of the ethnographic method and structured experiential learning activities (Badger \& MacDonald, 2007; Byram \& Feng, 2004; Roberts et al., 2001). There are further explorations of third spaces and contested spaces (Savignon \& Sysoyev, 2002). Student home culture is prescribed as a tool for bridging student cultural understanding (Baker, 2008; Çakir, 2006; Kim, 2002). Guest (2002) warns against contrastive analysis activities popularly known as cultural incidents because of the danger they pose for perpetuating essentialized views of the Other. Case studies in this time illustrate effective techniques for intercultural competence (Cruz, 2007; Liddicoat, 2006).

The appearance of the post-method condition (Kumaravadivelu, 2001, 2008) has a significant impact on culture teaching, especially in contexts of EIL, English for academic purposes, and English for specific purposes (Baker, 2009; Barletta, 2009; Nault, 2006). For example, teachers and students are to be treated as transcultural agents operating in global contact zones (Singh \& Dogherty, 2004), a reflection of the long challenge to received sources of authority in ELT. The post-method condition also casts teachers as mediators of culture learning rather than sources of cultural knowledge, as had been the arrangement in previous structuralist designs.

What becomes more pronounced in the 2000 literature set is the disconnect authors describe between ELT scholarship and the reported practices of in-service language teachers (Atay et al., 2009; Badger \& MacDonald, 2007; Barletta, 2009; Kim, 2002; Turizo \& Gómez, 
2006; Young et al., 2009). For example, Álvarez and Bonilla (2009) note that in-service teachers in Colombia struggle with intercultural communicative competence (ICC) and with postmodernist conceptions of culture. As a result, the teachers resort to static representations of culture and fact-based culture teaching. Authors argue that traditional models of teacher education are not working (Bayyurt, 2006) and that specific modules for ICC training are necessary (Agudelo, 2007; Paige et al., 2000; Young et al., 2009) so that language teachers can take students beyond superficial teaching of culture trivia. Schulz (2007) suggests a different tack: re-think objectives of ICC teaching in terms that are more modest and thus more attainable.

Authors also turn their critique to models of assessment for culture teaching (Byram \& Feng, 2004; Kim, 2002; Sercu, 2004). Risager (2000) notes the increasing need for explicit definitions of key terms so that valid and reliable methods of assessment can be developed. Textbooks for culture learning are also criticized for superficial treatments of cultural groups which are incompatible with poststructuralist visions (Bonilla, 2008; Paige et al., 2000).

\section{$2010 s$}

What is culture? In the literature reviewed from 2010-2015, the notion of culture continues to gain complexity as authors attach additional dimensions to it. A representative sample of a culture definition is found in Kramsch's (2015) articulation written for a global audience of intercultural education scholars:

Cultures are portable schemas of interpretation of actions and events that people have acquired through primary socialization and which change over time as people migrate or enter into contact with people who have been socialized differently. (p. 409)

The representative definition captures existing conceptual threads such as the challenge to traditional terms (Atkinson \& Sohn, 2013; Baker, 2012; J. Hall, 2012), avoidance of essentialized, static representations (Álvarez, 2014; Bonilla, 2012; Gómez, 2015; Sharifian, 2015) and the importance of context in interpreting cultural practices (Baker, 2012; Fandiño, 2014). On top of these existing threads, Kramsch's (2015) definition introduces additional defining characteristics: culture as mobile and cultural schema as changing over time. Other authors in the 2010s set locate culture in the interpersonal relationships that form in specific contexts (Castañeda, 2012; J. Hall, 2012).

The small set of $2010 \mathrm{~s}$ literature reveals three general themes. The first is continued work on viable alternatives to culture as a unit of analysis. The community of practice is one alternative model which sees expanded use in the 2010s (Cole \& Meadows, 2013; Sharifian, 2015). Atkinson and Sohn (2013) note the challenge in ELT to describe cultural practices when traditional terms are discredited, and propose a compromise approach termed cultural studies of the person. Nationalized cultures and essentialized cultures are increasingly 
problematized (Baker, 2012; Kramsch, 2015). A second theme is the continued re-framing of culture in ways consistent with the global realities of ELT. Following the post-method condition and the increasing visibility of ELF, EIL, and World Englishes, authority to determine what does and does not count as culture teaching is to be decided locally (Cogo, 2011; Fandiño, 2014; Izadpanah, 2011; Macías, 2010; Sharifian, 2015). A final theme is the transcendence of the familiar language/culture question. It is no longer a question if one should lead the other. Instead, it has become a question of whether or not they can be separated for teaching purposes. In the literature reviewed, there is movement to accept that culture cannot be separated from language but that cultural authority is to be determined in local settings (Baker, 2012; Cogo, 2011; Fandiño, 2014).

What does culture teaching look like? By the 2010s, Byram's (1997) intercultural communicative competence (ICC) constitutes the dominant view of how scholars define the content of ELT culture teaching (Álvarez, 2014; Baker, 2012; Bonilla, 2012; J. Hall, 2012, Sybing, 2011). Still, scholars in this set continue to refine their conceptualizations of what culture teaching should look like under an intercultural orientation. For example, Liddicoat and Scarino (2013) propose the intercultural perspective which places the focus on the language learner as both producer and interpreter of meaning in intercultural situations. Additional framing concepts bring pedagogical attention to intercultural education as a self-consciously inclusionary practice. These include critical cosmopolitanism (Holliday, 2011) and intercultural awareness (Baker, 2012). Scholars, like J. Hall (2012) acknowledge that although there are multiple conceptual models, there is little empirical evidence that they are effective, a criticism raised previously during the 2000s.

Other scholars in this set examine intercultural education as expressed in language policy documents. Liddicoat (2013), for example, demonstrates how policy texts reflect ideological understandings of the intercultural individual and thus project particular kinds of intercultural relationships for language teaching practice. In particular, Liddicoat's (2013) analysis shows how language-in-education policy can contribute to maintaining hegemonic conditions between groups in the particular intercultural identities that a policy affords- the privileged versus the marginalized (p. 216). Speaking as to the context of language-in-education policy in Colombia, Macías (2010) and Fandiño (2014) advocate for a re-alignment of national language education policy (i.e., Colombia Bilingüe) to reflect ELF and post-method perspectives as a corrective to the hegemonic positioning of BANA cultural models encoded in the current policy documents.

Goals for culture teaching in the 2010s literature set follow along at least two pathways. First, ICC as a learning objective tasks teachers with developing language learners who are able to mediate roles between cultural groups (Fandiño, 2014) in situations which are not pre-determined. As J. Hall (2012) puts it, teachers are to lead students in "pursuit of action in 
social worlds" (p. 48) but what those social worlds look like outside of the classroom emerges in context-specific ways. A second pathway is critical pedagogy. That is, ICC is also about helping students to take up action in their current and future social worlds in the interest of social equity and justice (Álvarez, 2014; Bonilla, 2012; J. Hall, 2012).

Scholars in the 2010s data set suggest a number of classroom techniques and activities that are consistent with the complex image of culture that has emerged. Experiential learning makes an appearance in the form of pragmatic ethnography, study abroad, exploring local culture, face-to-face intercultural talks, and project-based learning (Baker, 2012; Fandiño, 2014; J. Hall, 2012). Álvarez (2014) notes the successful use of social media platforms to bring language students together across geographical boundaries for meaningful intercultural exchange. Other more traditional classroom tasks include reflective class discussions, critical examination of authentic and textbook materials, exploration of media texts, class visits by cultural informants, and extending textbook dialogues (Gómez, 2015; McConachy \& Hata, 2013). Kramsch (2015, p. 414) encourages language teachers to move from the "safety of stereotypes" to "the riskiness of diversity" and to emphasize with students the symbolic power of discourse.

Scholars in this set communicate concerns with the practical implementation of culture teaching in language classrooms. Scholars point to the inadequacy of language textbooks for culture teaching (Álvarez, 2014; Castañeda, 2012; Gómez, 2015; McConachy \& Hata, 2013; Yuen, 2011). For example, Yuen (2011) shows how textbooks do not reflect an EIL perspective in the context of English language teaching in Hong Kong. In an analysis of three textbooks widely used in Colombian universities, Gómez (2015) determined that the content was limited to surface interpretations of culture and were thus not suitable for advancing student intercultural competence. As a corrective, Gómez directs language teachers to use the textbook materials as a launching point for critical examinations of deep culture in terms of "difference, power, ideology, identity, and even resistance" (p. 177). Other scholars identify an unfortunate disconnect between what scholars say about culture and what teachers are (not) doing with that information (Álvarez, 2014; Bonilla, 2012; Izadpanan, 2011; Kramsch, 2015; Olaya \& Gómez, 2013). For example, Álvarez (2014), in a review of the literature, concludes that the rapid move from the "culture-centered approach to the intercultural approach" (p. 234) in the context of Colombia may have helped engender teacher misconceptions of interculturality. Also in the same review, Álvarez (2014) brings attention to the issue of teacher education programs that do not sufficiently prepare language teachers for culture teaching according to intercultural models.

\section{Discussion}

Given the findings presented above, what are some general developments in how scholars approach culture teaching over the course of the years surveyed (1965-2015)? Looking first at 
the definition of culture, one observes that the concept of culture increases in complexity over time. One may think of a layering process. In the literature sets authors do not necessarily throw out the established concepts about culture from previous generations. They build on them, layer upon layer, until eventually they arrive at complex, multi-faceted definitions of culture represented in Kramsch (2015). By the 2010s set, culture is context-dependent, defined according to diverse subjectivities, mobile, and ever-changing. A second development observed in the literature is a transition in how scholars locate culture. In earlier writings, culture was something tied to a person. Predictability was high. Over time, however, authors came to describe culture in less-certain terms, locating it in the relationships that emerge when individuals interact in specific contexts. This development could be described as a transition from culture-in-the-person to culture-in-the-context.

Regarding the actual practice of culture teaching, treatments also developed over time. Three observations are possible. The first is that the role of the teacher shifted from being the center of cultural knowledge to the facilitator of knowledge — or more accurately-of intercultural development. Another observation is a movement between culture-specific to culture-general orientations. The culture-general orientation allowed for greater abstraction of teaching content over time. It also facilitated a re-thinking of what the endpoint for culture teaching should be. The term intercultural competence, which began as the ability to avoid cultural pitfalls, came instead to mean the ability to mediate cultural boundaries (e.g., intercultural identity). A third observation is the growing presence of critical theory in how ELT scholars are thinking about culture teaching. Specifically, one identifies sensitivity to power and inclusiveness that is not detectable in the earlier decade sets.

At the same time, there are observable consistencies across the literature sets. One is scholar concern with a perceived disconnect between culture teaching in theory and in actual classroom practice. Across the decade sets, we find expressed critique of culture teaching methods, commercially-available materials, assessment techniques, and teacher education programs. A second observation is that the developments in the literature are not absolute. In each decade set of readings, cultural definitions and culture teaching methodologies, deemed outdated by contemporaries, nevertheless are present. This review has purposively avoided using the term paradigm shift for this reason. Even in the postmodern climate of the current literature, studies that deploy theoretical concepts and teaching methods of previous decades are not difficult to find.

\section{References}

Agudelo, J. (2007). An intercultural approach for language teaching: Developing critical cultural awareness. Íkala, Revista de Lenguaje y Cultura, 12(18), 185-217.

Allen, W. (1985). Toward cultural proficiency. In A. C. Omaggio (Ed.), Proficiency, curriculum, articulation: The ties that bind (pp. 137-166). Middlebury, VT: Northeast Conference. 
Alptekin, C., \& Alptekin, M. (1984). The question of culture: EFL teaching in non-Englishspeaking countries. ELT Journal, 38(1), 14-20. http://dx.doi.org/10.1093/elt/38.1.14.

Álvarez, J. A. (2014). Developing the intercultural perspective in foreign language teaching in Colombia: A review of six journals. Language and Intercultural Communication, 14(2), 226-244. http://dx.doi.org/10.1080/14708477.2014.896922.

Álvarez, J. A., \& Bonilla, X. (2009). Addressing culture in the EFL classroom: A dialogic proposal. PROFILE Issues in Teachers' Professional Development, 11(2), 151-170.

Atay, D., Kurt, G., Çamlibel, Z., Ersin, P., \& Kaslioglu, Ö. (2009). The role of intercultural competence in foreign language teaching. Inonu University Journal of the Faculty of Education, 10(3), 123-135.

Atkinson, D. (1999). TESOL and culture. TESOL Quarterly, 33(4), 625-654. http://dx.doi.org/ $10.2307 / 3587880$.

Atkinson, D. (2004). Contrasting rhetorics/contrasting cultures: Why contrastive rhetoric needs a better conceptualization of culture. Journal of English for Academic Purposes, 3(4), 277-289. http://dx.doi.org/10.1016/j.jeap.2004.07.002.

Atkinson, D., \& Sohn, J. (2013). Culture from the bottom up. TESOL Quarterly, 47(4), 669-693. http://dx.doi.org/10.1002/tesq.104.

Badger, R., \& MacDonald, M. (2007). Culture, language, pedagogy: The place of culture in language teacher education. Pedagogy, Culture \& Society, 15(2), 215-227. http://dx.doi.org/10.1080/ 14681360701403722.

Baker, W. (2008). A critical examination of ELT in Thailand: The role of cultural awareness. RELC Journal, 39(1), 131-146. http://dx.doi.org/10.1177/0033688208091144.

Baker, W. (2009). The cultures of English as a lingua franca. TESOL Quarterly, 43(4), 567-592. http://dx.doi.org/10.1002/j.1545-7249.2009.tb00187.x.

Baker, W. (2012). From cultural awareness to intercultural awareness: Culture in ELT. ELT Journal, 66(1), 62-70. http://dx.doi.org/10.1093/elt/ccr017.

Barletta, N. (2009). Intercultural competence: Another challenge. PROFILE Issues in Teachers' Professional Development, 11(1), 143-158.

Bayyurt, Y. (2006). Non-native English language teachers' perspective on culture in English as a foreign language classrooms. Teacher Development, 10(2), 233-247. http://dx.doi.org/10.1080/ 13664530600773366.

Beaujour, M. (1969). Teaching culture in the foreign environment: Goals and non-Goals. The Modern Language Journal, 53(5), 317-320. http://dx.doi.org/10.1111/j.1540-4781.1969. tb04598.x.

Blatchford, C. (1973). Newspapers: Vehicles for teaching ESOL with a cultural focus. TESOL Quarterly, 7(2), 145-151. http:/ / dx.doi.org/10.2307/3585558.

Bonilla, X. (2008). Evaluating English textbooks: A cultural matter. HOW, 15(1), 167-192.

Bonilla, X. (2012). TEFL principles for teaching English in changing times. Colombian Applied Linguistics Journal, 14(2), 181-192. http://dx.doi.org/10.14483/udistrital.jour.calj.2012.2.a11. 
Broady, E. (2004). Sameness and difference: The challenge of culture in language teaching. Language Learning Journal, 29(1), 68-72. http://dx.doi.org/10.1080/09571730485200131.

Brooks, N. (1969). Teaching culture abroad: From concept to classroom technique. The Modern Language Journal, 53(5), 320-324. http:/ /dx.doi.org/10.1111/j.1540-4781.1969.tb04599.x.

Byram, M. (1992). Foreign language learning for European citizenship. Language Learning Journal, 6(1), 10-12. http://dx.doi.org/10.1080/09571739285200341.

Byram, M. (1997). Teaching and assessing intercultural communicative competence. Clevedon, UK: Multilingual Matters.

Byram, M., \& Feng, A. (2004). Culture and language learning: Teaching, research and scholarship. Language Teaching, 37(3), 149-168. http://dx.doi.org/10.1017/S0261444804002289.

Çakir, I. (2006). Developing cultural awareness in foreign language teaching. Retrieved from ERIC database. (ED494346).

Castañeda, M. E. (2012). Adolescent students' intercultural awareness when using culture-based materials in the English class. PROFILE Issues in Teachers' Professional Development, 14(1), 29-48.

Cogo, A. (2011). English as a lingua franca: Concepts, use, and implications. ELT Journal, 66(1), 97-105. http://dx.doi.org/10.1093/elt/ccr069.

Cole, D., \& Meadows, B. (2013). Re-imagining belonging: Communities of practice in the (foreign) language classroom. In D. Rivers \& S. Houghton (Eds.), Social identities and multiple selves in foreign language education (pp. 121-138). London, UK: Bloomsbury.

Crawford-Lange, L., \& Lange, D. (1984). Doing the unthinkable in the second-language classroom: A process for the integration of language and culture. In T. Higgs (Ed.), Teaching for proficiency: The organizing principle (pp. 139-177). Hastings-on-the-Hudson, NY: ACTFL.

Crozet, C., Liddicoat, A., \& Lo Bianco, J. (Eds.). (1999). Striving for the third place: Intercultural competence through language education. Melbourne, AU: Language Australia.

Cruz, F. (2007). Broadening minds: Exploring intercultural understanding in adult EFL learners. Colombian Applied Linguistics Journal, 9, 144-173.

Damen, L. (1987). Culture learning: The fifth dimension in the language classroom. Reading, MA: Addison-Wesley.

Debyser, F. (1968). The relation of language to culture and the teaching of culture to beginning language students. CCD Language Quarterly, 6, 1-8.

De Mejía, A. (2006). Bilingual education in Colombia: Towards a recognition of languages, cultures and identities. Colombian Applied Linguistics Journal, 8, 152-168.

Fandiño, Y. J. (2014). Teaching culture in Colombia Bilingüe: From theory to practice. Colombian Applied Linguistics Journal, 16(1), 81-92. http://dx.doi.org/10.14483/udistrital.jour. calj.2014.1.a07.

Fischer, M. (1967). Contrastive cultural features in FL teaching. Slavic and East European Journal, 11(3), 302-307. http://dx.doi.org/10.2307/304502.

Gómez, L. F. (2015). The cultural content in EFL textbooks and what teachers need to do about it. PROFILE Issues in Teachers' Professional Development, 17(2), 167-187. http://dx.doi.org/ 10.15446/profile.v17n2.44272. 
Guest, M. (2002). A critical "checkbook" for culture teaching and learning. ELT Journal, 56(2), 154-161. http://dx.doi.org/10.1093/elt/56.2.154.

Hall, E. (1976). Beyond culture. New York, NY: Anchor Books.

Hall, J. (2012). Teaching and researching: Language and culture (2nd ed.). New York, NY: Routledge.

Higgs, T. (1988). Language as culture: Teaching culture from a functional perspective. In I. Mailhot-Bernard \& D. Cashman (Eds.), Canada's languages: A time to reevaluate (pp. 74-84). Halifax, NS: Canadian Association of Second Language Teachers.

Holliday, A. (1999). Small cultures. Applied Linguistics, 20(2), 237-264. http://dx.doi.org/ 10.1093/applin/20.2.237.

Holliday, A. (2011). Intercultural communication and ideology. Los Angeles, CA: Sage.

Holmes, J., \& Brown, D. (1976). Developing sociolinguistic competence in a second language. TESOL Quarterly, 10(4), 423-431. http://dx.doi.org/10.2307/3585523.

Imhoof, M. (1968). Controlling cultural variations in the preparation of TESOL materials. TESOL Quarterly, 2(1), 39-42. http://dx.doi.org/10.2307/3585441.

Izadpanah, S. (2011). The review study: The place of culture in English language teaching. US China Foreign Language, 9(2), 109-116.

Jacobson, R. (1976). Incorporating sociolinguistic norms into an EFL program. TESOL Quarterly, 10(4), 411-422. http://dx.doi.org/10.2307/3585522.

Kachru, B. (Ed). (1982). The other tongue: English across cultures. Champaign, IL: University of Illinois Press.

Kim, J. (2002). Teaching culture in the English as a foreign language classroom. The Korea TESOL Journal, 5(1), 27-40.

Kramer, J. (2000). Cultural studies. In M. Byram (Ed.), Routledge encyclopedia of language teaching and learning (pp. 162-164). London, UK: Routledge.

Kramsch, C. (1987). Foreign language textbooks' construction of foreign reality. The Canadian Modern Language Review, 44(1), 95-119.

Kramsch, C. (1993). Context and culture in language teaching. Oxford, UK: Oxford University Press.

Kramsch, C. (1998). Language and culture. Oxford, UK: Oxford University Press.

Kramsch, C. (2006). From communicative competence to symbolic competence. The Modern Language Journal, 90(2), 249-252. http://dx.doi.org/10.1111/j.1540-4781.2006.00395_3.x.

Kramsch, C. (2015). Language and culture in second language learning. In F. Sharifian (Ed.), The Routledge handbook of language and culture (pp. 403-416). London, UK: Routledge.

Krasnick, H. (1982). Beyond communicative competence: Teaching culture in ESL. TESL Reporter, 15(3), 45-49.

Kubota, R. (1999). Japanese culture constructed by discourses: Implications for applied linguistics research and ELT. TESOL Quarterly, 33(1), 9-35. http://dx.doi.org/10.2307/3588189.

Kumaravadivelu, B. (2001). Toward a postmethod pedagogy. TESOL Quarterly, 35(4), 537-560. http://dx.doi.org/10.2307/3588427.

Kumaravadivelu, B. (2008). Cultural globalization and language education. New Haven, CT: Yale University Press. 
Lado, R. (1957). Linguistics across cultures. Ann Arbor: MI: University of Michigan Press.

Lafayette, R. (1978). Teaching culture: Strategies and techniques. Washington DC: Center for Applied Linguistics.

Lafayette, R., \& Schulz, R. (1975). Evaluating cultural learnings. In R. Lafayette (Ed.), The culture revolution in foreign language teaching (pp. 104-118). Skokie, IL: National Textbook Company.

Lewald, H. (1963). Problems in culture teaching. The Modern Language Journal, 47(6), 253-256. http://dx.doi.org/10.1111/j.1540-4781.1963.tb06664.x.

Liddicoat, A. (2006). Learning the culture of interpersonal relationships: Students' understandings of personal address forms in French. Intercultural Pragmatics, 3(1), 55-80. http://dx.doi.org/ 10.1515/IP.2006.003.

Liddicoat, A. (2013). Language-in-education policies: The discursive construction of intercultural relations. Bristol, UK: Multilingual Matters.

Liddicoat, A., \& Scarino, A. (2013). Intercultural language teaching and learning. Malden, MA: Wiley-Blackwell. http://dx.doi.org/10.1002/9781118482070.

Macías, D. F. (2010). Considering new perspectives in ELT in Colombia: From EFL to ELF. HOW, 17(1), 181-194.

Matthies, B. (1968). TESOL at the "5 \& 10". TESOL Quarterly, 2(4), 280-284. http://dx.doi.org/ $10.2307 / 3585926$.

McConachy, T., \& Hata, K. (2013). Addressing textbook representations of pragmatics and culture. ELT Journal, 67(3), 294-301. http://dx.doi.org/10.1093/elt/cct017.

Moore, Z. (1995). Teaching and testing culture: Old questions, new dimensions. International Journal of Educational Research, 23(7), 595-606. http://dx.doi.org/10.1016/0883-0355(96)80439-3.

Moore, Z., Morales, B., \& Carel, S. (1998). Technology and teaching culture: Results of a state survey. CALICO Journal, 15(1-3), 109-128.

Morain, G. (1983). Commitment to the teaching of foreign cultures. The Modern Language Journal, 67(4), 403-412. http://dx.doi.org/10.1111/j.1540-4781.1983.tb01525.x.

Murphy, E. (1988). The cultural dimension in foreign language teaching: Four models. Language, Culture, and Curriculum, 1(2), 147-163. http://dx.doi.org/10.1080/07908318809525033.

Nababan, P. (1974). Language, culture, and language teaching. RELC Journal, 5(2), 18-30. http://dx.doi.org/10.1177/003368827400500203.

Nault, D. (2006). Going global: Rethinking culture teaching in ELT contexts. Language, Culture and Curriculum, 19(3), 314-328. http://dx.doi.org/10.1080/07908310608668770.

Nostrand, H. (1989). Authentic texts and cultural authenticity: An editorial. The Modern Language Journal, 73(1), 49-52. http://dx.doi.org/10.1111/j.1540-4781.1989.tb05310.x.

Nostrand, F., \& Nostrand, H. (1970). Testing understanding of the foreign culture. In H. Seelye (Ed.), Perspectives for teachers of Latin American culture (pp. 161-170). Springfield, IL: Illinois State Office of the Superintendent of Public Instruction.

Olaya, A., \& Gómez, L. F. (2013). Exploring EFL pre-service teachers' experience with cultural content and intercultural communicative competence at three Colombian universities. PROFILE Issues in Teachers' Professional Development, 15(2), 49-67. 
Oxford, R. (1995). Teaching culture in the language classroom: Toward a new philosophy. In J. Alatis (Ed.), Georgetown University round table on languages and linguistics, 1994 (pp. 26-45). Washington DC: Georgetown University Press.

Paige, R., Jorstad, H., Siaya, L., Klein, F., \& Colby, J. (2000). Culture learning in language education: A review of the literature. St. Paul, MN: Center for Advanced Research on Language Acquisition.

Pennycook, A. (1999). Introduction: Critical approaches to TESOL. TESOL Quarterly, 33(3), 329-348. http://dx.doi.org/10.2307/3587668.

Pennycook, A. (2000). History: After 1945. In M. Byram (Ed.), Routledge encyclopedia of language teaching and learning (pp. 275-282). London, UK: Routledge.

Povey, J. (1967). Literature in TESL programs: The language and the culture. TESOL Quarterly, 1(2), 40-46. http://dx.doi.org/10.2307/3585752.

Ramsey, C. (1981). Cultural understanding for global citizenship: An inservice model. In M. Conner (Ed.), A global approach to foreign language education: Selected papers from the 1981 Central States Conference (pp. 17-22). Skokie, IL: National Textbook Company.

Risager, K. (2000). Cultural awareness. In M. Byram (Ed.), Routledge encyclopedia of language teaching and learning (pp. 159-161). London, UK: Routledge.

Risager, K. (2007). Language and culture pedagogy: From a national to a transnational paradigm. Clevedon, UK: Multilingual Matters.

Roberts, C., Byram, M., Barro, A., Jordan, S., \& Street, B. (2001). Language learners as ethnographers. Clevedon, UK: Multilingual Matters.

Savignon, S., \& Sysoyev, P. (2002). Sociocultural strategies for a dialogue of cultures. The Modern Language Journal, 86(4), 508-524. http://dx.doi.org/10.1111/1540-4781.00158.

Saville-Troike, M. (1978). A guide to culture in the classroom. Rosslyn, VA: National Clearinghouse for Bilingual Education.

Scanlan, T. (1979). Teaching British and American language and culture with the aid of mail-order catalogues. ELT Journal, 34(1), 68-71. http://dx.doi.org/10.1093/elt/34.1.68.

Schulz, R. (2007). The challenge of assessing cultural understanding in the context of foreign language instruction. Foreign Language Annals, 40(1), 9-26. http://dx.doi.org/10.1111/ j.1944-9720.2007.tb02851.x.

Seelye, H. (1968). Culture in the foreign language classroom. Springfield, IL: Illinois State Office of the Superintendent of Public Instruction.

Seelye, H. (1977). Teaching the cultural context of intercultural communication. In M. Saville-Troike (Ed.), Georgetown University round table on languages and linguistics (pp. 249-256). Washington DC: Georgetown University Press.

Sercu, L. (2004). Assessing intercultural competence: A framework for systematic test development in foreign language education and beyond. Intercultural Education, 15(1), 73-89. http://dx.doi.org/10.1080/1467598042000190004.

Sharifian, F. (2015). Language and culture: Overview. In F. Sharifian (Ed.), The Routledge handbook of language and culture (pp. 3-17). London, UK: Routledge. 
Simpson, C. (1997). Culture and foreign language teaching. Language Learning Journal, 15(1), 40-43. http://dx.doi.org/10.1080/09571739785200091.

Singh, P., \& Doherty, C. (2004). Global cultural flows and pedagogic dilemmas: Teaching in the global university contact zone. TESOL Quarterly, 38(1), 9-42. http://dx.doi.org/10.2307/ 3588257.

Strasheim, L. (1981). Language is the medium, culture is the message: Globalizing foreign languages. In M. Conner (Ed.), A global approach to foreign language education: Selected papers from the 1981 Central States Conference (pp. 1-16). Skokie, IL: National Textbook Company.

Sybing, R. (2011). Assessing perspectives on culture in EFL education. ELT Journal, 65(4), 467-469. http://dx.doi.org/10.1093/elt/ccr025.

Taylor, J. (1970). Direct classroom teaching of cultural concepts. In H. Seelye (Ed.), Perspectives for teachers of Latin American culture (pp. 42-50). Springfield, IL: Illinois State Office of the Superintendent of Public Instruction.

Taylor, D., \& Sorenson, J. (1961). Culture capsules. The Modern Language Journal, 45(8), 350-354. http://dx.doi.org/10.1111/j.1540-4781.1961.tb03550.x.

Trager, G. (1962). What kind of culture does the language teacher teach? In B. Choseed (Ed.), Report of the eleventh annual round table meeting on linguistics and language studies (pp. 135-138). Washington DC: Georgetown University Press.

Trivedi, H. (1978). Culture in language learning. ELT Journal, 32(2), 92-7. http://dx.doi.org/ 10.1093/elt/XXXII.2.92.

Tseng, Y. (2002). A lesson in culture. ELT Journal, 56(1), 11-21. http://dx.doi.org/ 10.1093/elt/56.1.11.

Turizo, J., \& Gómez, P. (2006). Intercultural communication and ELT: A classroom experience. HOW, 13(1), 139-152.

Weiss, G. (1971). The language teacher: An interpreter of culture. Die Unterrichtspraxis / Teaching German, 4(1), 36-42. http://dx.doi.org/10.2307/3528934.

Widdowson, H. (1994). The ownership of English. TESOL Quarterly, 28(2), 377-389. http:// dx.doi.org/10.2307/3587438.

Young, T., Sachdev, I., \& Seedhouse, P. (2009). Teaching and learning culture on English language programmes: A critical review of the recent empirical literature. International Journal of Innovation in Language Learning and Teaching, 3(2), 149-169. http:/ /dx.doi.org/10.1080/ 17501220802283178.

Yuen, K. (2011). The representation of foreign cultures in English textbooks. ELT Journal, 65(4), 458-466. http://dx.doi.org/10.1093/elt/ccq089.

\section{The Author}

Bryan Meadows (Ph.D., University of Arizona) is an associate professor in the Sammartino School of Education at Fairleigh Dickinson University. His research interests include intercultural education, classroom discourse, and second language teacher education. 